\title{
Film as a pedagogical tool for geography during the pandemic induced virtual classes
}

\author{
Rima Mullick • Sk. Safikul Haque
}

Accepted: 17 February 2022 / Published online: 7 March 2022

(C) The Author(s), under exclusive licence to Springer Nature B.V. 2022

\begin{abstract}
Film has always been an important medium to disseminate social issues through imageries and imaginaries. The present paper examines the importance of film in understanding contextual, geographical concept-metaphors through virtual classes that can unearth the potential of the teaching-learning process in the COVID-19 induced lockdown situation. Qualitative techniques are used here to analyze landscapes, communication and actions to reveal the importance of a film from Bollywood, the world's largest film producing hub, in the context of teaching geographical concepts via online digital-mode classes in the ongoing pandemic scenario. Besides, Bollywood film has a wider and strong subliminal effect on the human mind. In this connection, the present work shows how a teachers' team use geographic media literacy as a pedagogical tool to enhance their students' cognition in online classes. It further shows that film acts as a geographic teaching tool for making students aware of the subjective understanding of Geography through a sub-branch wise explanation of cinematic components. It is observed that, even in the absence of classroom activity, if the lecture/study
\end{abstract}

R. Mullick $(\bowtie)$

Department of Geography, University of Calcutta, 35, B.

C. Road, Kolkata 700019, India

e-mail: rima.mullick@gmail.com

S. S. Haque

Department of Geography, Kharagpur College,

Kharagpur 721305, India materials are interlinked with film, it would render a good understanding of the required geographical know-how. This article thus introduces a new scope for devising a better and more resilient online teaching process that promises to enrich geographical studies' digital pedagogy.

Keywords Lockdown - Online teaching - Film · Media literacy $\cdot$ Peepli Live $\cdot$ Digital pedagogy

\section{Introduction}

The world has been largely affected by the novel Corona virus disease (COVID-19) in every societal aspect (Mishra, Gayen, et al., 2020). In this pandemic situation, lockdown and social distancing is the only way to prevent people from being affected by the severe acute respiratory syndrome coronavirus 2 (SARS-CoV-2) (Gayen et al., 2021). After the declaration of a global pandemic by WHO on 11th March 2020, schools and higher education institutions across the globe have been closed, impacting vast numbers of students (Hasan \& Khan, 2020). In-person teaching in academic institutions across India has been discontinued since the middle of March 2020, and the virtual teaching-learning process was the only feasible option left in the COVID-19 induced lockdown period (Dhawan, 2020). Generally, a teacher has to meet the requisite standard quality of teaching needed to fulfill a particular course and its curriculum 
(Dhimitri et al., 2018). Teachers and students of primary to tertiary level were compelled to embrace this pedagogical shift from the overwhelmingly traditional classroom and black-white board method to a modern digital platform approach (Giannini et al., 2021; Mishra, Gupta, et al., 2020). Though this method acts as a redeemer, teachers find it challenging to entirely resolve students' doubts (Dhawan, 2020). While text book-dependent teaching in Geography has been a robust way of communication (Esteves, 2019), it has been a real challenge to provide effective learning e-content/e-resources during the long and sustained lockdown conditions. In this backdrop, teachers are trying to utilize pictorial and diagrammatic teaching aids for better understanding and visualization. In Geography, both nature and human society are essential subject matter. Thus, the cinematic representation in the online teaching mode makes understanding the subject more effective. For this purpose, freely available film from digital archives can be used by the teacher-student community. In this, the teacher's perception, and explanations regarding the landscape, communication and action shown in film play a vital role in developing communication skills, cognitive ability, and writing (BFI, 2003). Further, film can help students develop a deeper understanding of the spatial association with scenic landscapes (Lukinbeal, 2005). Film is a continuous representation, a reel mosaic about landscapes using sounds, light, texture, motion. These cinematic experiences leave an impression on our mind (Escher, 2006; Lukinbeal \& Zimmermann, 2008). The visualization of these images increase our comprehensibility of space, the conceptual and unbounded unit of earth science (Elwood, 2011), along with the dynamic human imprints upon it (Crang, 2009). However, while film-based study initially in geography was primarily found in Human and Behavioral Geography (Kennedy \& Lukinbeal, 1997), it has gained substantial importance in various other sub-fields since then. Geographic research has used film to bring forward regional issues, present social problems, and address local developments (Aitken, 1991; Dasgupta \& Patel, 2017; Sellam, 2014).

Further research has focused on the geographical uniqueness of regions to the rest of the world (Aitken \& Zonn, 1994; Alderman \& Popke, 2002; BFI, 2005; Lukinbeal \& Zimmermann, 2006). During the pandemic times when virtual classes are the dominant medium of teaching, film can be an effective visual representation. Film is a cultural product and imparts a regional identity, values, and meanings (Tuan, 1979; BFI, 2005; BFI, 2015; Doel, 2008; Kirby, 2021; Sunikka-Blank et al., 2020; UIS, 2016) through geographic media literacy (Lukinbeal, 2014). Similarly, it gives a geographical explanation, historical information, and recreation to people (Orueta \& Valdes, 2009) even when they cannot visit the field and are maintaining social distancing.

Geography's tryst with ideas on terrae incognitae (Wright, 1947) has a lingering effect on its research and teaching potential. The discipline inspects all the components of art (Tuan, 1990), mass media (Brooker-Gross, 1983), and their existing domains. Jameson (1992) and Villarejo (2007) considered film as a pre-eminent art of post modernity. Now, the analysis of media representation under the movie-making system has become more vital for space-time relation to understand society in the light of a postmodern perspective (Harvey, 1992). As a result of the cultural turn in social sciences, the use of film in Geography teaching was introduced in 'The Geographical Magazine' in 1950s for the first time (Aitken, 1994). 'Film Geography' gradually became one of the pivotal themes of geographical teaching, geographic media literacy, research and pedagogy (Algeo, 2007; Ansell, 2002; Barrance, 2010; Cresswell \& Dixon, 2002; Hintermann et al., 2020; Lukinbeal, 2014; Palma, 2009; Patel, 2021; Tuan, 1979). However, the main focus on geographical teaching was on documentary films and landscape representation. That was until 1994 when Aitken and Zonn put forward the anti-essentialist perspective of film and pedagogy (Aitken \& Dixon, 2006) which was applied in various dimensions of classroom activity. At the beginning of the twenty-first century, Alderman and Popke (2002) vividly showed how a satirical television news magazine can be used as a media resource in geography pedagogy. At time, few specific societal issues as well as natural phenomena from film, have been incorporated into research and academic platform such as cityscape and its issues (Bose, 2008; Mennel, 2008), ethnicity, diasporas and migration issues (Algeo, 2007), and cinematic cartography (Caquard \& Taylor, 2009; Castro, 2009), film tourism (Juškelytè, 2016). Satyajit Ray's and Mrinal Sen's research help one to understand the basic canvas of the urban landscape and modernity in the post-colonial context with in the Indian scenario (Bose, 2008; Woods, 2015). With 
the growing use of film in pedagogy and research, geographic media literacy has become a necessity. Hintermann et al. (2020) had vividly explained the implementation of critical media literacy using models, toolkits and individual media practice in geographic education and pedagogy. Drawing inspiration from Palma (2009), Lukinbeal (2014) and Hintermann et al. (2020) this study uses geographic media literacy to show deeper cognition and 'leanercentered' education in this highly complex societal system.

This paper puts forward motion pictures as an effective and resilient teaching mode. In sync, it examines the role of Indian film in understanding geographical processes, especially when classroom teaching is not possible to conduct. The following section links the visualizing aspects of film and geography pedagogy for managing the current teaching crisis engendered by online classes. Then the basic research design of this present work has been described with the help of the teachers' team, content analysis, and keyword-based data mining procedure. Finally, discussion and analysis are under taken using one of the films from Bollywood as an example to show the various scopes of using a film in the subject domain of Geography for teaching through online virtual classes.

\section{Film and geography teaching for crisis management in india}

After independence, 'Geography' in India became an exciting subject to inquisitive pupils which discussed the landscape of faraway places. Geography has been taught from two broad spectrums, physical and human geography, at both school and higher education. Although it's teaching in the higher education ecosystem is being performed by well-designated teachers at colleges and universities (UGC, 2001), at the dawn of the twenty-first century, most of the geography taught in schools is by non-geographer teachers as a subbranch of social sciences (Tiwari, 2012) without having geography as their subject in their undergraduate course (Alam, 2015). The higher education curriculum is much more diversified, detailed and practical oriented than the school system. Lecture, storytelling, and activity-based methods are very common in the school system, whereas travelogue and observation are frequently used in higher education. Observation, recording, and interpretation of the physical and social features and phenomena are key targets of the teaching process using common aids to build students' mental maps (Bhardwaj, 2016). Unlike other subjects, in Geography, an observational discipline, students are more interested in using slides or pictures of features in audio-visual mode (Mangal \& Mangal, 2012). Film as a pedagogical device is also the sole means of information facilitator about a particular theme of the subject (Bhardwaj, 2016). Along with meta-analysis, students can be motivated to examine their opinions and build their geographical imageries of the world after watching moving pictures (Champoux, 2007; Dhand, 1990). Due to lack of teaching infrastructure and scarcity of awareness, the imprint to film geography is not well developed as a mode of geographic pedagogy in India. Although policy makers have advocated the application of information and communication technology (ICT) in teaching, it is very rare to find its applicability in school teaching. Even in colleges, it is mostly used in situations like special lectures, seminars, or workshops. Over the last few decades, film has become a more popular medium for the teaching-learning process in developed countries to convey the knowledge of the unknown. From this viewpoint, it is a vital pedagogical agent to represent the world (Burgess \& Gold, 1985; Castro, 2018). Before March 2020, board work, practical exercises and field-based observational understanding of the subject's content were used at the utmost level. However, during COVID, all these were not possible in the online teaching method.

It is one of the critical and challenging tasks among geography teachers to make students understand the geographical facts and figures in the present-day pandemic world. Films represent the world even in the online teaching mode; and for many, it portrays the unsung picture of day-to-day life (Costa, 2013; Kennedy \& Lukinbeal, 1997). Therefore, it is appropriate to use Bollywood film in the online teaching-learning process. This cinematographic attempt instigates geographical imagination and clarifies the geographical imageries that help learners view spatial patterns and processes of various phenomena from different perspectives to generate critical thoughts and dialogue (Clark, 1970; Fioravante, 2013). Since India has been the largest movie making country from 1998 (UIS, 2016); there is a broad scope to analyze 
the cinematic texts in the geography teaching pedagogy. However, only a few efforts have examined this opportunity in the ongoing, long pandemic situation. Besides, most such research explains only some pictures, clips, and plots from film to make students understand basic concepts.

In contrast, our research shows how popular Bollywood film can be used to teach various sub-fields of geography. Thus, how will geography teaching be more effective to the pupil community in a distance learning system living in lockdown conditions when conventional and direct teaching methods are not possible? This article highlights the scope and utilization of Bollywood Film in the pedagogy of Geography and its 'media literacy' during the COVID lockdown.

\section{Data set and methodology}

Formulation of teachers' team

A team of teachers is identified through purposive sampling, comprising five teachers at different academic levels (Table 1) to perceive film effectiveness among their respective students during their online classes from May to December 2020. The purpose of research, research objectives, research design and their respective role in this research work was communicated to all the teachers. All are duly interested in mainstream film, which is available in online streaming media service, with educational value and national significance that mirrors contemporary issues of developing countries like drought, farmer distress, hunger, and rural to urban migration as portrayed in the chosen film in this study-Peepli Live (2010). They insisted their students to watch the film repetitively before screening the film in virtual class and built mental images on different aspects of the subject. Peepli Live was selected based on a unanimous decision of the team. The film won various awards, was positively reviewed as a contemporary and thought-provoking film, and was much discussed in daily news for its relevance to most parts of India.

Identification of dominant branches

We examined the curriculum of Geography at the under-graduate (UG) level (including general and degree courses) and post-graduate (PG) (considering elementary and core courses) section from the hundred-and-ninety leading universities of India. The West Bengal Higher-secondary (HS) geography syllabus is also incorporated for in-depth micro-level scenarios (Fig. 1). After the close examination of course curriculum and film, fourteen most commonly used and taught branches/ sub-fields of Geography under two broad categories have been extracted, these are (a) Physical Geography-Geomorphology, Climatology, Environment, Bio-geography and Hydrology; and (b) Human Geography-Agriculture, Economic, Population, Settlement, Social, Cultural, Regional Planning and Development, Regional Geography of India. These sub-fields have been considered since they are the most taught branches in Geography and are closely related to film. Authors had prepared a frequency table of various fields of geography and calculated the percentage for UG level and PG level separately (Table 2), considering the criteria for final selection of the most taught sub-fields, where each subfield atleast in one level of education should have 50 percent or more value indicating that, the subfields taught in a minimum of 50 percent of the
Table 1 Structure and criteria of teachers' team

\begin{tabular}{llllll}
\hline Person & Age (yrs) & Gender & $\begin{array}{l}\text { Subject experi- } \\
\text { ence }(\mathrm{yrs})\end{array}$ & Occupation & $\begin{array}{l}\text { Occupation } \\
\text { experience } \\
\text { (yrs) }\end{array}$ \\
\hline I & 52 & Female & 36 & School Teacher & 23 \\
II & 41 & Male & 25 & Assistant Professor & 10 \\
III & 35 & Male & 19 & Assistant Professor & 9 \\
IV & 32 & Female & 16 & School Teacher & 8 \\
V & 31 & Male & 15 & Lecturer & 6 \\
\hline
\end{tabular}


Fig. 1 Conceptual framework of research design and workflow
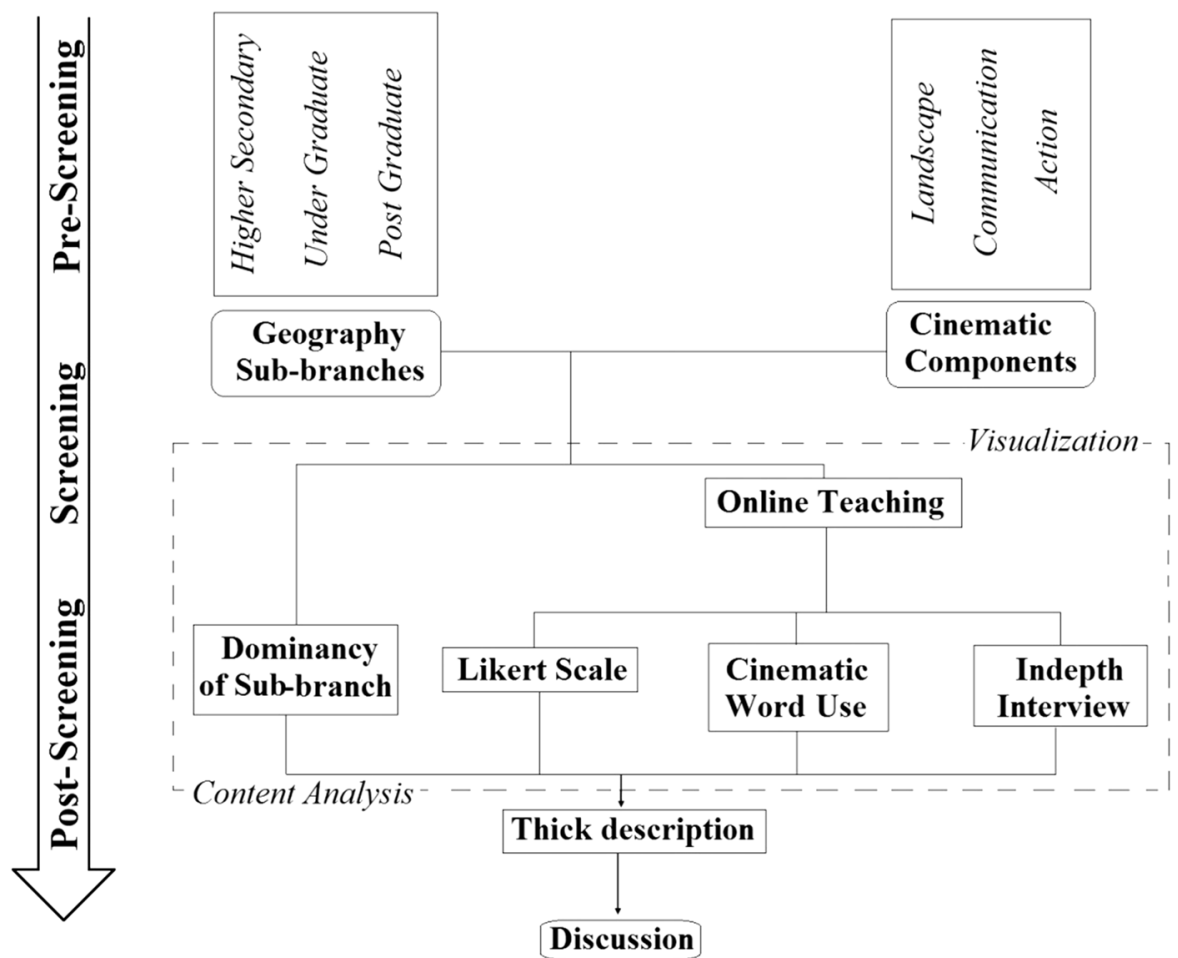

Table 2 Most taught sub-field of geography in under-graduate and post-graduate course of selected Indian universities $(\mathrm{N}=190)$

\begin{tabular}{lll}
\hline Sub-field of geography & $\begin{array}{l}\text { Under } \\
\text { graduate } \\
\text { (in \%) }\end{array}$ & $\begin{array}{l}\text { Post } \\
\text { graduate } \\
\text { (in \%) }\end{array}$ \\
\hline Geomorphology & 100 & 100 \\
Climatology & 100 & 98 \\
Environment geography & 83 & 78 \\
Bio-geography & 49 & 57 \\
Hydrology & 46 & 51 \\
Economic geography & 98 & 88 \\
Regional geography of India & 95 & 87 \\
Population geography & 88 & 90 \\
Regional planning and development & 79 & 85 \\
Settlement geography & 78 & 68 \\
Agriculture geography & 65 & 75 \\
Social geography & 53 & 73 \\
Political geography & 41 & 69 \\
Cultural geography & 28 & 62 \\
\hline
\end{tabular}

selected Universities, showing its importance in the curriculum.

\section{Design for analysis of film components}

The following components of the film played the most vital role for the teaching pedagogy during the online classes are (a) communication: whether it is verbal or non-verbal; (b) Landscape: comprising the location (narrative and filmed) and territory (beyond the immediate surrounding); (c) action: emotion, experience, and association of the scenic characteristics. During the virtual class conducted by the five teachers in their respective schedule, the film was screened, each shot or scene was paused and explained from the perspective of these three components of film from the prism of geography. The team conducted this screening in various phases (from May to December, 2020) and after each class, teachers conducted an interactive session where the student had to participate with their verbal subjective discussion and feedback with the teacher. The selected components have been analyzed using visualization, content analysis, in depth interviews and thick description. Peepli Live (2010) was scrutinized 


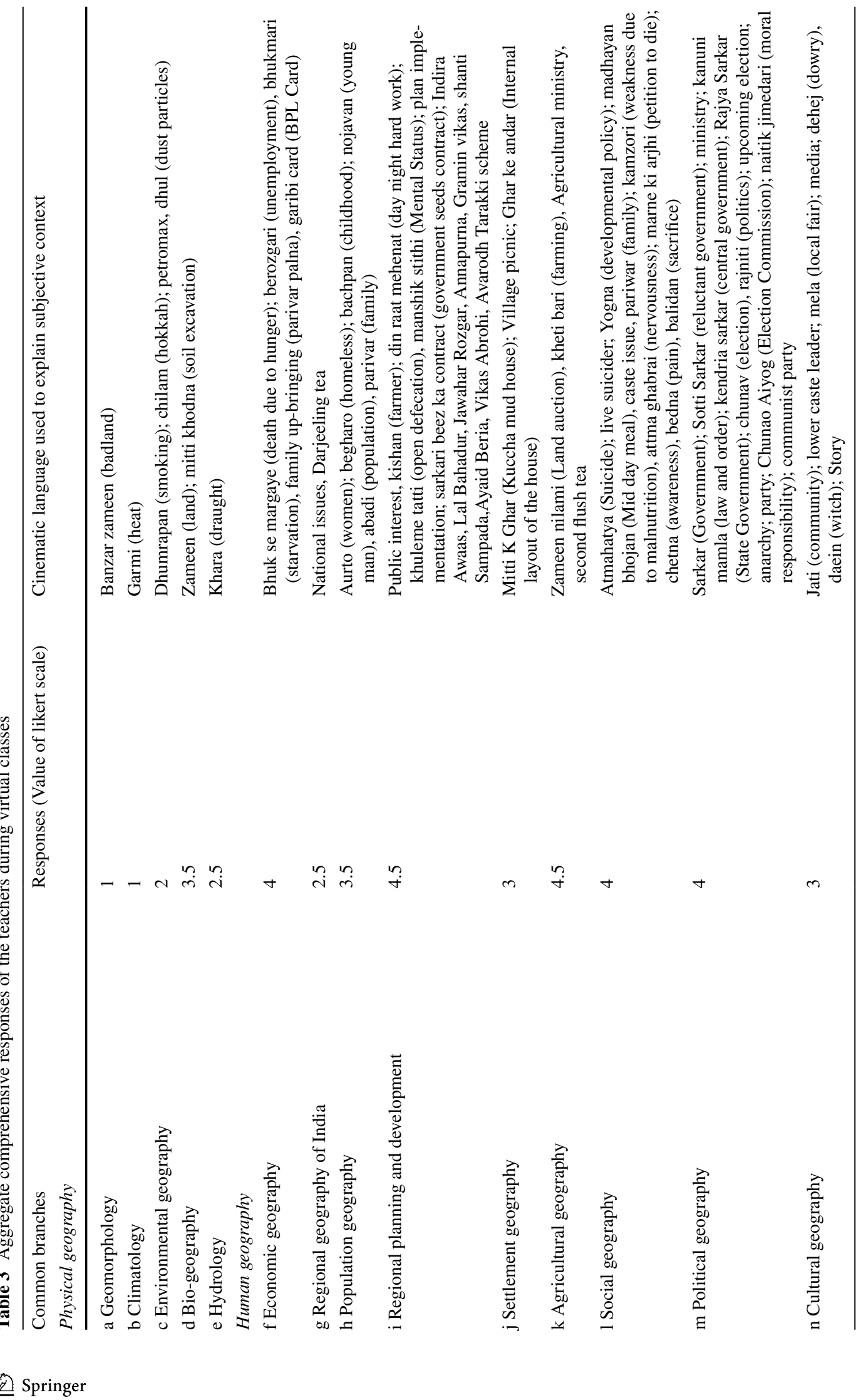


under the different branches of geography through a non-participatory action research technique. The authors and the teacher team scrutinized the use of the film for the subject matter of each sub-branch from the virtual teaching experience. For this, the team assigned the average value on a 5-point Likert scale (Table 3) from the classroom interaction for detailed assessment. Each team member had used this film to explain the various sub-fields of geography during their teaching process and had given 1-5 points based on students' comprehensive feedback during the class (indicating 1 as minimum level and 5 as maximum level). The team had also mentioned various verbal words from the film that are relevant or related to the particular sub-field of geography that they had used to explain the subject during the online class. The authors conducted in-depth interviews of the teachers for accounting and collating the respective teaching experiences and discussions in the virtual class that they had shared. The occurrence and repetition of the subject matter in terms of time (seconds) for Peepli Live was calculated for further analysis (Fig. 2).

\section{Result and discussion}

Peepli Live (a Hindi movie, 2010) is written by Anusha Rizvi and directed jointly by Anusha Rizvi and Mahmood Farooqui. The film captured pertinent socio-economic-political issues in Indian agrarian society, representing many geographical subfields. Peepli Live is a satirical comedy enacted in Bhopal, Indore, Tikamagarh, Khurai, and Gurgaon. The basic theme is the impact of globalization, water crisis, crop failure, political dilemma, and unfair media reporting that creates an ongoing 'live' dilemma for the local village inhabitants. Most of the film is situated in a village, diverging from conventional Bollywood plots. But, it also shows the infrastructural imprints of urban advancement. Here, 'Peepli' is a fictional and imaginary village, reflective of rural
Fig. 2 Dominance of subbranches in relation to the repeated time in total shown time in the film

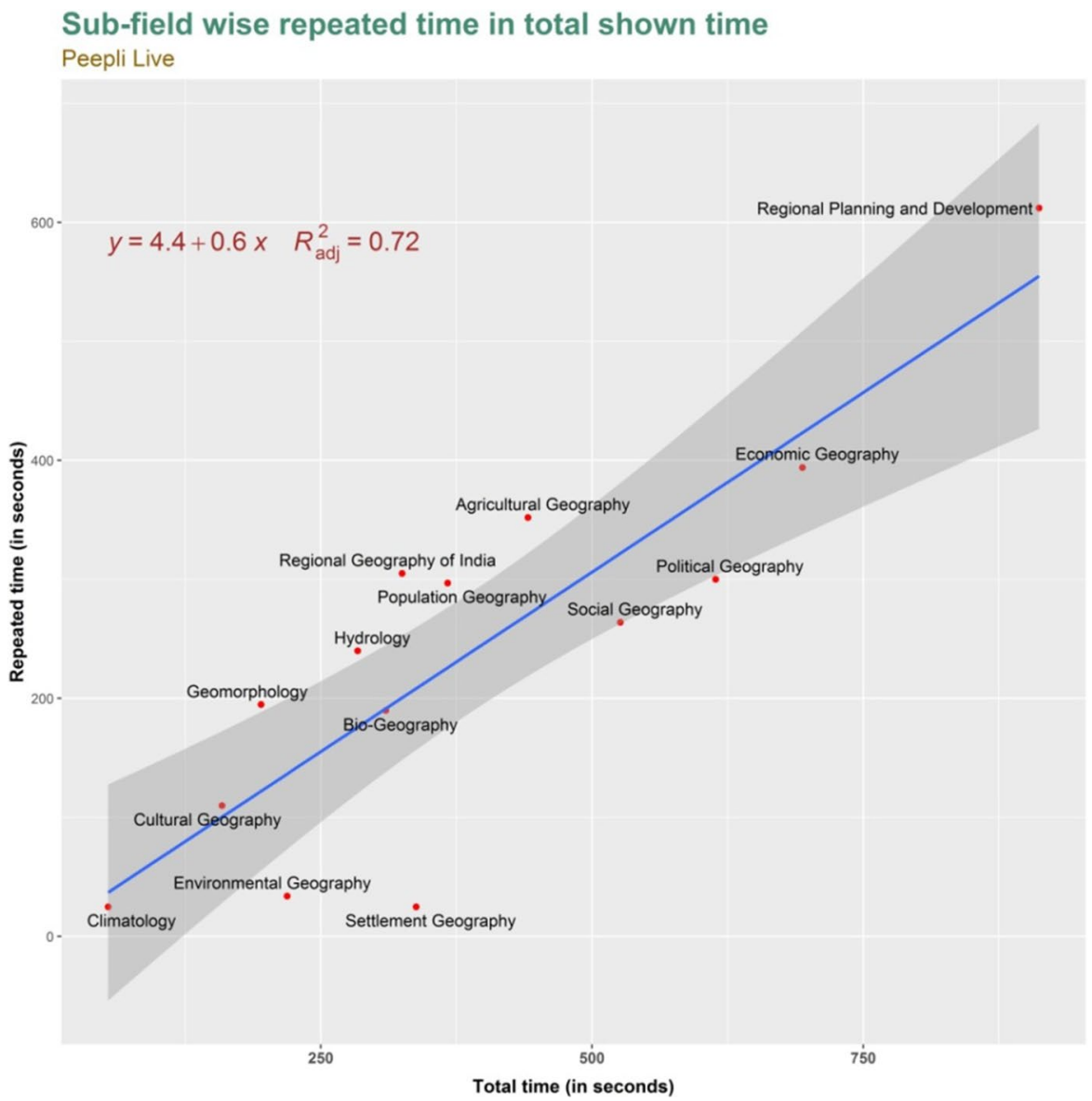


life in central India. The film revolves around a central character, Nathadas, also known as Natha, who is a poor farmer with his family. It provides a vivid image of poor farmers' socioeconomic condition and their efforts against the contemporary situation of the fragile economic and social condition. Based on three parameters-communication, landscape and action of the motion picture-this film portrays regional planning and development, economic, political, social and agriculture geography, in the context of a contemporary issue in the recent agriculture society under the influence of globalization forces. According to the teachers' team, the film's verbal and non-verbal communication and actions portrayed a clear economic and political geography picture to students. Natha's elder brother wanted him to commit suicide to pressure the local administration for financial help and assistance for better agricultural aid, farming practices and livelihood. It shows that 'Natha', the leading character, was compelled to commit suicide because of an economic crisis and a debt burden that had made the family sell their land to the bank. This instance indicates an economic crisis in the Indian rural agrarian society. It also allows a pedagogic examination of India's contemporary neoliberal economic geography. Gradually, it brings forward various dimensions of social lives and aspects of regional development in India. This film portrayed the rural livelihood and showed how poverty, money lending and its vicious cycle, together with illiteracy, have molded the lives of poor people in rural areas despite suitable opportunities for sustainable and profitable agricultural practices. Peepli Live brings forward the population structure of the tribal family, house type and rural morphology. The cinematography shows these concepts associated with territorial expression (landscape) and emotional expression (actions). Here, this film acts as an embodiment of the social process that inhabits society. Through both communication and action, a 'live crisis' in our society is given more credence (and more time on the media airwaves) than actual problem in a rural Indian village, is portrayed in the film. The film is pointing to social issues, improper plan implementation, poverty, and an imbalance in wealth distribution. There was an instance where Natha's wife, while addressing to media, expresses her unhappiness about Natha's suicide, about the role of a bank, the local government, activities of the village head and land auction: she is thoroughly disgusted with the whole situation. She rebukes her husband that he did not find it necessary to inform her about his intention of committing suicide. Through both verbal and non-verbal communication and actions, these instances reveal the gender scenario of the society. In the film, the women are seen doing all the household chores while men deal with other situations, which mirror the gender and family relationships in Indian society. Based on the class room feedback, the teachers' team has ascertained these aspects were well understood during their virtual classes through this motion picture. In the film, there is another scene where an emaciated old man, Hori Mahto, excavates soil from a land surrounded by a green agriculture field adjacent to his hut. The collected top soil from the pit is sold in the brick kilns and earns 30-40 rupees a day. He was compelled to do so because he had lost his agricultural land to the money lender. Hori Mahto embodies the farmer's condition in the region. Removing topsoil for brick kilns and other allied development activities over utilizing the fertile agriculture field is one of the burning issues in the vast plain regions of India (Haque, 2011). A strong representation of poverty, hunger, selling of agricultural land due to debt, daily meager earning for sustenance and the reason for the presence of brick kiln in the village fringe were well understood by the students in their online classes. Non-verbal expression represents the vicious cycle of poverty, malnutrition, soil excavation, hard work, occupation scenario, economic crisis and regional imbalance. Whereas the location component of this scene shows that Hori Mahto's massive pit by his hut indicates that the old man does not have any land of his own. On the other hand, the territorial representation of lush agricultural lands nearby with their lush crops in the fields shows that the region is suitable for cultivation. However, access to the agriculture land and an economic livelihood is not available for some. Concomitantly, the physical geography of the film is clearly evident in the outlines of undulating ground, indicating a plateau fringe region showcases the topography of central India. The actions depicted a hand-to-mouth livelihood of despair and no hope for society. Later in the film, the man dies in the pit that he dug, which is ironic and an eye-opener for the students.

There is a scene where another prominent character, 'Rakesh', a local news reporter, while having 
a conversation with his senior, sounded a little disturbed with the death of the old farmer and the government's reluctance towards improving the situation of other poor farmers. He verbalizes the povertystricken older man, who was equally helpless, indebt, landless and malnourished, but the upper class and decision-makers are primarily interested in the story of one man who was brought into the limelight, i.e. Natha. Here, Rakesh represents the issues of regional planning and development with a planning imbalance and impoverished agrarian life. The economic geography of the regions is lucidly depicted when Rakesh talks about poverty, hunger, the selling of soil, and the earning of a very minimal daily wage. On the other hand, Rakesh depicted political and social geography as the government's ignorance and the stark difference between the 'have's' and 'have not's'. This films shows an overt equivalence to Indian economy and policy failure in rural areas while acting as an active agent to represent the 'virtual-space' of reality. In a particular scene, the agricultural bureaucrats, through verbal expression, mention various policies and divisions of work between the state and the central government related to agriculture and rural population, mainly focused on the regional geography of India, planning and development. This film shows through action and communication how the environment played a vital part in shaping the livelihood of the people of India. In a few scenes, the village fair, folk traditions and art and rural games were shown, which shows how a small village economy revolves around small changes and how one is interlinked with the other. Social hierarchy and bonding are portrayed vividly in the film.

A particular situation in this film shows a reporter of an eminent news channel asking his camera man to shoot the morning report mentioning that $70 \%$ of the villagers in India are defecating in the open. Even though it seems sad, around two-thirds of India still practices this, which leads to numerous illnesses and aggravates poverty and low economic development (Clasen et al., 2014). In this film, a new and unused set of tube-well are highlighted which is a striking and sarcastic representation of the water shortage and showed that the family does not have money to dig the borehole of tube-well. Since it was given to Natha's family as a gift by the local political representative as an election is about to come, it indicates their ignorance of the actual problem and the need of these poor people in their locality. Towards the end of the story, the death of the local reporter occurred due to a political and media 'dance'. The accidental death of the local reporter due to the commotion between media, political and administrative personnel was represented as Natha's death. The death of the old, hunger-stricken, malnourished farmer was foregone by everyone with ease; instead, the death of the person who didn't want to die made the news. This film showed how the deprived rural life is insignificant against poverty, hunger, and political dilemma. It opens a window for the students to see the real rural scenario, agricultural crisis, and farmers' condition in India. The last scene of this film has a vital location and action representation. The gradual transition from agrarian to progressive urban development shows a remarkable gap between urban and rural scenarios. The migrant labourers are seen working in a developmental project, clearly indicating the lives of the migrant population and their occupational shift in the urban setting. Based on the 5-point Likert scale, this film's contribution towards the student understanding of the various sub-fields of geography was measured (Table 3 ). Regional planning and development and Agricultural Geography are widely portrayed in this film which explains it scoring 4.5. Some examples of these sub fields include the green revolution and its consequences, impact of globalization on agriculture, genetically modified organisms (GMOs), the role of agriculture on human society from the platform of agrarian society, and development of the underdeveloped regions. Political, social and economic geography scored 4.0 on the same scale. Various aspects of these subfields include primary economic activity, issues related to the development and environment linkage, problems associated with sustainable resource development and conflictcrisis-compromise, contemporary socio-environmental issues with particular reference to India, environment and poverty.

In comparison, social differentiation and stratification, social processes, quality of life, social well-being and its measurement, housing, gender disparity, social exclusion, communal conflicts, rural crime, social policy in India are key social geography elements portrayed. At the end of the film, the entire socio-cultural landscape culminates with an economic fallacy and regional political event. Population geography and bio-geography has scored 3.5 (Table 3). Loss of 
soil fertility, including land degradation and soil excavation, were examples of biogeography shown in the film. People from an isolated tribe in a rural society played the lead role in this film, highlighting population geography. Rural house type and building material, rural morphology, rural governance, housing and social segregation highlighted settlement geography. Signatures of urbanization, infrastructural development, production of space and labor sources are also visualized at the end of the film. More specifically, issues regarding the regional development and ethics of mass communication and journalism were also shown. From the in-depth interview of the teachers' team and their feedback from classroom interaction shows that students gained a clear overview and were cognitive on the different sub-fields presented through Peepli Live.

The most dominant branches shown in this film were social, political, settlement, economic geography, as well as regional development and planning. All these covered more than 50 percent of the total film time. Based on the computed co-efficient of determinants/determination $\left(\mathrm{R}^{2}\right)$, cultural and economic geography, bio-geography, and climatology (Fig. 2) are closer to the average trend of total time shown and the times they are repeated. Although scene enactment on regional geography of India and climatology individually is very little, agriculture geography, hydrology, cultural geography and population geography have deep impressions on the overall subject matter. Regional-political issues are more prominent in this film portrays federal policy and state-nation relation is more dominant than a global perspective. Hence, regional planning and development has the maximum amount of time portrayed in the film and is a recurring element in the film. There was a moderate span of time screened environment and bio-geography. However, in terms of shots and scene consideration, both environment and settlement geography have played strong roles in this film.

Through this research, we showed how this film offered new topical topics for virtual teaching domain. In this study, regional planning and development has more nodal values in online teaching because of the portrayal of a wide variety of regional and local issues of people from different political backgrounds and people's behavioral responses. The Census of India has stated that the present situation of agriculture-based rural livelihood has been such that 'eight million farmers quit farming in India between 1991 and 2001' (The Hindu, 2010), which is still being experienced in large parts of central India. In 2014, the total number of farmer suicides was recorded as 5,650 in the NCRB report, and eastern Maharashtra is considered the epicenter of India's farmer suicide (Rao et al., 2017; Rukmini, 2015). These concepts are well understood from the geographical viewpoint by the students during online digital classes.

\section{Conclusion}

In a pandemic induced crisis where students find difficulties in coping with the new medium of teaching, the subjective analysis of film for understanding complex concepts helps them develop the critical philosophical potential for engaging with geographical discourses. We have observed and portrayed the vast impact of Peepli-Live in the online teaching process in the context of representation of various aspects of social and environmental entities like agricultural landscape, tribal livelihood, cultural mosaic, urban infrastructural advancement, and space and time integration with the fiction regarding farmers' livelihood and background sceneries of the surroundings of rural India. Peepli-Live offers a wide range of knowledge to build students' geographical imaginations. It helps one to understand the basic canvas of repetitive landscape and action in the societal context of the Indian farmer suicide scene to a large extent. Regarding this scene, the student groups all learned embedded series of geographical concepts. Digital pedagogy during lockdown effectively communicates images that remain etched in a learner's mind. Geographic media literacy based on online teaching reveals contemporary views and ideas of society and effectively makes the current issues known to students. Since the last decade of the twentieth century, the wave of globalizing market economy has successfully entered rural India through film and its allied activities (BFI, 2005). Thus, we have to be open to using this advantage in the nation's 'education for all' program, even in the current long running pandemic condition. It would bring the academic endeavor to the grassroots level, which can be vital in spreading quality education and reducing drop-outs in a lockdown context. As most of the students are 
well-versed with mobile gadgets/applications, telecommunications and internet use, it makes it easier to avail the film to watch it repetitively. Therefore, even in the absence of classroom activity, if the lecture/study material is interlinked with film; it would render a good understanding of the required conceptual know-how. Besides, it puts forward the complex and vital components of the real world in front of the student and makes it easier for ordinary people to comprehend complex but faraway or close to home issues in short span of time. It is crucial for the film that is chosen to be available to all, along with the consideration that its language may need to be understood by the majority of the classes or that there be suitably provided succinct subtitles. Furthermore, the teacher should have prior in-depth knowledge about the film to be shown in class and should also guide the student so that they can extract the maximum knowledge from the film, while not seeking to impose all of their views so that there is space for imaginative reconfigurations of the seen components. Proper and repetitive presentation of the crucial sequences in a film is necessary and active participation of both the teacher and student is obligatory. Each film is unique in its way and if it is appropriately presented, this vast resource will boost the teaching-learning process. This work shows a broad scope for using film in pedagogy for geographical explanation through online education, where both physical and human branches have equal opportunity to be explored. It is apparent from the study that different films can explain different sub-fields of geography, similar to how we have explained the cinematographic representation of Peepli-Live for explaining the significant facets of human, cultural and regional aspects of geography through any mode of teaching. Furthermore, such endeavors can spread social awareness at the grassroots level to cope with the present difficulties of the society. Subsequently, such pedagogic attempts shall remove the digital gap barrier and spread real-time techno-centric knowledge in local society. It becomes more pertinent during pandemic times when the deep digital divide in a global south country like India restricts the accessibility and feasibility of online classes for many.

Acknowledgements We are thankful to Prof. Sumana Bandyopadhyay, University of Calcutta; Prof. Sanjukta Sattar,
University of Mumbai, Prof. Priyank P. Patel, Presidency University and Mr. Swasti Vardhan Mishra, Rabindra Bharati University, Kolkata, for their continuous encouragement and help. The first author would like to acknowledge, the University Grant Commission (UGC), Government of India for providing fellowship. The authors are grateful to the editor and reviewer for valuable suggestions and insights.

Authors' contributions RM: writing original draft, design of methodology, investigation and supervision; Sk.SH: conceptualization and data mining.

Availability of data and material All the data and materials are available at official website and e-cloud.

Code availability Not Applicable.

\section{Declarations}

Conflict of interest The authors declared that there is no conflict of interest to disclose.

Consent to participate The authors agreed commonly to participate.

Consent for publication The authors ensure the consent for publication in this journal.

Ethical approval We ensure that our paper is self explanatory and well cited

\section{References}

Aitken, S. C., \& Zonn, L. (1994). Re-presenting the place pastiche. In S. Aitken \& L. Zonn (Eds.), Place, power situation and spectacle: A geography of film (pp. 3-25). Rowman and Littlefield Publishers Inc.

Aitken, S. (1991). A transactional geography of the imageevent: The films of Scottish director, Bill Forsyth. Transaction, Institute of British Geographers, 16(1), 105-118. https://doi.org/10.2307/622909

Aitken, S. C. (1994). I'd rather watch the movie than read the book. Journal of Geography in Higher Education, 18(3), 291-307.

Aitken, S. C., \& Dixon, D. P. (2006). Imagining geographies of film. Erdkunde, 60(4), 326-336.

Alam, S. (2015). A note on the status of the geography teachers in Indian schools. Geographical Education, 28, 59-65. https://search.informit.org/doi/10.3316/ielapa. 84592 2392101092

Alderman, D. H., \& Popke, E. J. (2002). Humor and film in the geography class room: Learning from Michael Moore's TV nation. Journal of Geography, 101(6), 228-239. https://doi.org/10.1080/00221340208978506

Algeo, K. (2007). Teaching cultural geography with bend it like Beckham. Journal of Geography, 106(3), 133-143. https://doi.org/10.1080/00221340701632781 
Ansell, N. (2002). Using films in teaching about Africa. Journal of Geography in Higher Education, 26(3), 355-368.

Barrance, T. (2010). Using film in schools: A practical guide. UK Film Council. Film: 21st Century Literacy. http:// www.filmeducation.org/pdf/misc/C21_Using_film_in_ schools.pdf

BFI (British film Institute). (2003). Look again: A teaching guide to using film and television with three-to elevenyear olds. ISBN: 1-903786-11-8. www.bfi.org.uk/educa tion

BFI (British film Institute). (2005). The impact of local cinema: Overview. This report was produced with the support of UK Film Council Lottery Fund, Film London, E M Media and British film Institute (BFI). November 05 (pp. 1-76). https://www.bfi.org.uk/sites/bfi.org.uk/files/downloads/ uk-film-council-impact_of_local_cinema-2005-11.pdf, on 18.04.2020 at 8:00 p.m.

BFI (British film Institute). (2015). A framework for film education. Co-funded by European Union and Creative Europe Media. https://www2.bfi.org.uk/sites/bfi.org.uk/ files/downloads/\%20bfi-a-framework-for-film-educationbrochure-2015-06-12.pdf

Bhardwaj, B. P. (2016). Syllabus for bachelor of education (B. Ed.) programme (pp. 41-51). Department of Teacher Education, NCERT.

Bose, B. (2008). Modernity, globality, sexuality, and the city: A reading of Indian cinema. The Global South, 2(1), 35-58.

Brooker-Gross, S. R. (1983). Spatial aspects of Newsworthiness. Geografiska Annaler, Series B, Human Geography, 65(1), 1-9.

Burgess, J., \& Gold, J. (1985). Place, the media and popular culture. In J. Gold \& J. Burges (Eds.), Geography, the media and popular culture (pp. 1-32). St. Martin's Press.

Caquard, S., \& Taylor, D. R. F. (2009). What is cinematic cartography? The Cartographic Journal, 46(1), 5-8. https:// doi.org/10.1179/000870409X430951

Castro, F. V. (2018). The use of film in geography and history classes: A theoretical approach. Proceedings, 2(21), 1360. https://doi.org/10.3390/proceedings 2211360

Castro, T. (2009). Cinema's mapping impulse: Questioning visual culture. The Cartographic Journal, the British Cartographic Society, 46(1), 9-15.

Champoux, J. E. (2007). Film as a teaching resource. Journal of Management Inquiry, 8(2), 240-251. reprint and updated in September 26, 2007.

Clark, M. J. (1970). Physical geography on film. Geographical Association, 55(1), 16-26.

Clasen, T., Boisson, S., Routray, P., Torondel, B., Bell, O. M., Cumming, J., Ensink, M., Freeman, M., Jenkins, A., Sinha, M., Suar, W. P., \& Schmidt. (2014). Effectiveness of a rural sanitation programme on diarrhoea, soiltransmitted helminth infection, and child malnutrition in Odisha, India: a cluster-randomised trial. Lancet Global Health, 2(11), e645-e653. https://doi.org/10.1016/S2214109X(14)70307-9

Costa, J. C. (2013). Spatial representations of squatter settlement in visual narratives of Brazilian films: a comparative cinematic landscape analysis of Black Orpheus, City of God and Elite Squad I \& II. In A.F.de Azevedo, R. N. Martins, M. Rodrigues, \& M. Santos (Eds.), Geographical imaginations. Book of proceedings of IV international meeting in cultural geography. Geographical imagination (Vol. 3, pp.185-208). ISBN: 978-989-97394-2-0.

Crang, M. (2009). Visual methods and methodologies. In D. DeLyser, S. Herbert, S. Aitken, M. Crang, \& L. McDowell (Eds.), Handbook of qualitative geography (pp. 208225). Sage.

Cresswell, T., \& Dixon, D. (2002). Introduction: Engaging film. In T. A. Cresswell \& D. Dixon (Eds.), Engaging film: Geographies of mobility and identity (pp. 1-10). Lanham.

Dasgupta, R., \& Patel, P. P. (2017). Examining the physical and human dichotomy in geography: Existing divisions and possible mergers in pedagogic outlooks. Geographical Research, 55(1), 100-120.

Dhand, H. (1990). Techniques of teaching. Anish Publishing House.

Dhawan, S. (2020). Online learning: A panacea in the time of COVID-19 crisis. Journal of Educational Technology, 49(1), 5-22.

Dhimitri, J., Gjegjaj, L., \& Dushi, E. (2018). Assessing professional standards of geography teachers in the municipality of Lezha, Albania. European Journal of Geography, Association of European Geographers, 9(4), 105-124.

Doel, M. A. (2008). From animated photography to film: The formation of vernacular relativity in early English Films (1895-1908). In C. Lukinbeal \& S. Zimmermann (Eds.), The geography cinema-A cinematic World, geographie. Media geography (Vol. 1, pp. 87-99). Franz Steiner Verlag.

Elwood, S. (2011). Geographic information science: Visualization, visual methods, and the geoweb. Progress in Human Geography, 35(3), 401-408. https://doi.org/10.1177/ 0309132510374250

Escher, A. (2006). The geography of cinema-A cinematic world. Erdkunde, 60(4), 307-314.

Esteves, M. H. (2019). Geography teachers' views on textbook use in Portugal: A small scale study in challenging time. European Journal of Geography, Association of European Geographers, 10(1), 85-98.

Fioravante, K. E. (2013). Spaces of transgression and normativity in Pedra Almodòvar's filmography. In A. F. Azevedo, R. N. Martins, M. Rodrigues, \& M. Santos (Eds.), Geographical imaginations (pp. 37-54). Blackwell.

Gayen, A., Haque, S. K., \& Mishra, S. V. (2021). COVID19 induced lockdown and decreasing particulate matter (PM10): An empirical investigation of an Asian megacity. Urban Climate, 36 (March 2021), 100786. https://doi.org/ 10.1016/j.uclim.2021.100786

Giannini, S., Jenkins, R., \& Saavedra, J. (2021). Mission: Recovering education 2021. Posted on 30th march 2021 by Gem Report. https://gemreportunesco.wordpress.com/ 2021/03/30/mission-recovering-education-2021/

Haque, S. M. (2011). Environmental impact of the removal of top soil for bricks construction from agricultural field: A case study of Midnapore block. Indian Journal of Regional Science, RSAi., 43(1), 124-132.

Harvey, D. (1992). The condition of post modernity: An inquiry into the origins of cultural change. Blackwell.

Hasan, N., \& Khan, N. H. (2020). Online teaching-learning during COVID-19 pandemic: Students' perspective. Journal of Distance Education and e-Learning, 8(4), 202-213. 
Hintermann, C., Bergmeister, F. M., \& Kessel, V. A. (2020). Critical geographic media literacy in geography education: Findings from the MiDENTITY project in Austria. Journal of Geography, 119(4), 115-126. https://doi.org/ 10.1080/00221341.2020.1761430

Jameson, F. (1992). The geopolitical aesthetic: Cinema and space in the world system. Indiana University Press.

Juškelytė, D. (2016). Film induced tourism: Destination image formation and development. Regional Formation and Development Studies, 19(2), 54-67. https://doi.org/10. 15181/rfds.v19i2.1283

Kennedy, C., \& Lukinbeal, C. (1997). Towards a holistic approach to geographic research on film. Progress in Human Geography, 21(1), 33-50.

Kirby, P. (2021). Geography and film music: Musicology, gender, and the spatiality of instrumental music. Transactions of the Institute of British Geographers, 46(1), 570-583. https://doi.org/10.1111/tran.12443

Lukinbeal, C., \& Zimmermann, S. (2008). A cinematic world. In C. Lukinbeal \& S. Zimmermann (Eds.), The geography cinema-A cinematic world. Geographie: Media geography (1st ed., pp. 15-23). Franz Steiner Verlag.

Lukinbeal, C. (2005). Cinematic landscape. Journal of Cultural Geography, 23(1), 3-22.

Lukinbeal, C. (2014). Geographic media literacy. Journal of Geography, 113(2), 41-46. https://doi.org/10.1080/00221 341.2013.846395

Lukinbeal, C., \& Zimmermann, S. (2006). Film geography: A new subfield. Erdkunde, 60(4), 315-325.

Mangal, S. K., \& Mangal, U. (2012). Essentials of educational technology. PNI Private Limited.

Mennel, B. (2008). Cities and cinema. Routledge.

Mishra, S. V., Gayen, A., \& Haque, S. M. (2020). COVID-19 and urban vulnerability. Habitat International, 103 (September 2020), 102230. https://doi.org/10.1016/j.habitatint. 2020.102230

Mishra, L., Gupta, T., \& Shree, A. (2020). Online teachinglearning in higher education during lockdown of COVID19 pandemic. International Journal of Educational Research Open, 1(2020), 100012. https://doi.org/10. 1016/j.ijedro.2020.100012

Orueta, A. G., \& Valdes. C. M. (2009). Cinema and Geography: Geographical space, landscape and territory in the film industry (translated version from 'Boletín de la Asociación de Geógrafos Españoles'. 45, 157-190).

Palma, M. T. D. (2009). Teaching geography using films: A proposal. Journal of Geography, 108(2), 47-56. https:// doi.org/10.1080/00221340902967325

Patel, P. P. (2021). Exploring geotools and geomedia to augment the classroom curriculum: A brief overview. In S. Mukherjee \& S. Sarkar (Eds.), Population health and regional development: Issues and challenges. Orangebooks Publication.

Rao, T. S. S., Gowda, M. R., Ramachandran, K., \& Andrade, C. (2017). Prevention of farmer suicides: Greater need for state role than for a mental health professional's role. Indian Journal of Psychiatry, 59(1), 3-5.

Rukmini, S. (2015). India's new farm suicides data: Myths and facts. The Hindu, July 24, 2015. article7461095.ece.

Sellam, P. (2014). Cinema as a tool for development: Investigation the power of mobile cinema in the Latin American context. M.Sc. Thesis, Utrecht University, pp. 1-110.

Sunikka-Blank, M., Bardhan, R., Schupp, J., Prabhu, J., \& Penz, F. (2020). Films as source of everyday life and energy use: A case of Indian cinema. Energy Research \& Social Science, 69 (November 2020), 101655. https://doi. org/10.1016/j.erss.2020.101655

The Hindu. (2010). Farm suicide: A 12 year saga. Article written by P. Sainath, Updated 15th December 2016. https:// www.thehindu/opinion/columns/sainath/farmsuicidea12y earsaga/article16811575.ece

Tiwari, P. S. (2012). A Note on the teaching of Geography in India. Contributory paper presented in symposium on teaching and research in geography in India, organized by the Centre for Earth Science Studies, Thiruvananthapuram, Kerala (India) on December 12-14, 2012.

Tuan, Y. (1979). Sight and pictures. Geographical Review, 69(4), 413-422. https://doi.org/10.2307/214804

Tuan, Y. (1990). Realism and fantasy in art, history, and geography. Annals of the Association of American Geographers, 80(3), 435-446.

UGC. (2001). Report of the curriculum development committee in geography, 2001. University Grant Commission (UGC).

UIS (UNESCO Institute for Statistic). (2016). Diversity and the film industry: An analysis of the 2014 UIS survey on feature film statistics. UNESCO Institute for Statistic. https:// doi.org/10.15220/978-92-9189-190-0-en

Villarejo, A. (2007). Film studies: The basics. Routledge.

Woods, M. N. (2015). Calcutta and the modern woman: Reading the film Mahanagar and Kahaani. The Global South, 9(2), 85-102. https://doi.org/10.2979/globalsouth.9.2.05

Wright, J. (1947). Terrae incognitae: The place of imagination in geography. Annals of the Association of American Geographers, 37(1), 1-15.

Publisher's Note Springer Nature remains neutral with regard to jurisdictional claims in published maps and institutional affiliations. 